compromise is not a suboptimal solution, for the kind of consensus and normative agreement that is often thought necessary for constitutional politics to work is both unrealistic and contrary to a political conception of pluralism. For his part, Olsen explores the question of whether a public philosophy emerges from the Convention proceedings and the draft constitution, and whether such public philosophy offers a reasonable vision of Europe. His answer, however, is that though the constitution-making process has contributed to the emergence of a democratic dialogue on a European public philosophy, this is far from settled and the discussion over the constitution must carry on.

As for the contributions on the substantive values of the constitutional document, it is difficult to do justice to them in the brief compass of this review. The topics covered go from the idea of liberty (Dobson) to representation (Smisman) and transparency (Naurin); from the role of rights and judicial power (Attucci and Gargarella, respectively) to new practices of decision making such as the Open Method of Co-ordination (Tsakatika). As the editors remark in their conclusion, besides offering some illuminating insights on the legitimacy of the European integration process, the application of the normative approach to the European constitutional debate provides elements of reflection on political theory itself, and how many of the categories and distinctions that characterize more abstract debates are often presented in too stark terms, while the application of political theorizing to concrete situations may require a more nuanced adaptation so as to capture the multi-dimensional aspects of political reality.

Dario Castiglione University of Exeter, UK.

\title{
Pluralism
}

William E. Connolly

Duke University Press, Durham NC and London, 2005, 208pp. ISBN: 0822335670.

Contemporary Political Theory (2007) 6, 122-125. doi:10.1057/palgrave.cpt.9300292

William Connolly has written about pluralism for quarter of a century. Over the past 10 years, he has developed his own distinctive 'post-Nietzschean' conception of 'multidimensional pluralism'. Pluralism resembles Connolly's previous publications both in terms of its form and content. This is not a criticism, there is difference in Connolly's repetitions, and this is an important 
contribution to his corpus. The originality of Pluralism is Connolly's greater appreciation that pluralism is under threat. As the title of the book indicates, this is a manifesto. Pluralism outlines the 'civic virtues' appropriate to pluralism in the context of 'aggressive campaigns against pluralism', in the context of 9/11, Al Qaeda, the Guantanamo 'Gulag', and American-Israeli 'humiliation' of the Palestinians (pp. 5, 13-14, 53).

The book is comprised of five essays that are linked thematically, although each can be read as a discrete unit. In Chapter 1, Connolly explores the relationship between pluralism and 'evil', commencing with an analysis of the ideas of Augustine, Spinoza, and Sayyid Qutb: 'the radical cleric whose version of Islam is said to inspire Osama bin Laden' (p. 17). Connolly asks, how can the faithful coexist 'on the same strip of territory', in a world where (theistic or non-theistic) 'faith' is indispensable, and people embrace a variety of faiths? Given the insufficiency of the secular relegation of faith to the private sphere, the faithful must adopt a 'bicameral orientation' to citizenship (p. 31). A pluralist brings 'chunks' of her faith into the public realm, but she refrains from the impulse to 'territorial unitarianism' inscribed in her faith, she refrains from the desire to 'convert' everyone with whom she interacts. Instead, she listens to the 'call to tolerance' embedded in her faith in order to practice 'agonistic respect' or 'restrained contestation', as she negotiates public settlements with those who confess alternative faiths (pp. 31-34). These themes are further elaborated in Chapter 2, which investigates the relationship between pluralism and 'relativism'. Through a critique of Leo Strauss and the rise of American neo-conservatism, Connolly makes the case that pluralism is not relativism. The relativist works with a 'concentric image of culture' (one homogenous culture relative to each strip of territory), and has real difficulty with the 'problem' of 'minorities'. Whereas, the pluralist acknowledges the 'complexity of culture' and seeks to embody the 'civic virtues of pluralism' in her relational practices with others (p. 65).

Chapter 3 examines the relationship between pluralism and the 'universe'. Here, Connolly presents an account of William James's 'metaphysical pluralism', with references along the way to Henri Bergson and some other bedfellows in current cosmology and biology. James's 'pluralistic universe' is not presided over by an omnipotent God, 'escapes' the logic of a rational Whole, is irreducible to a fixed set of laws, and is filled with 'litter': there is an inherent 'element of chance' within its 'loose regularities' (pp. 71-73). In Chapter 4, Connolly continues to map the pluralistic universe through a consideration of the relationship between pluralism and 'time'. Drawing principally on Bergson, Connolly contrasts the artifice of 'clock time' with the lived experience of 'durational time' or 'becoming' (p. 102). He elaborates a phenomenology of the 'flow of time', where past (qua perceptible and 
imperceptible memory traces) and present (qua modes of perception, action, and judgment) coexist in a 'crystallization of time' that 'opens onto an undetermined future' (pp. 103-106). The civics lesson of these chapters is that the (political) pluralist should adopt an attitude of 'critical responsiveness' to new and insurgent becomings, in a world characterized by 'unpredictable changes' and where politics moves at an ever-faster pace.

Chapter 5 investigates the relationship between pluralism and 'sovereignty' and focuses on the tension between sovereign power and the rule of law (on the paradoxical 'lawlessness upon which law depends'), with recourse to the ideas of Rousseau, Tocqueville, and Giorgio Agamben. Connolly admires Agamben's account of the conjunction between biopolitics and sovereign power. However, the 'zone of instability' that sovereignty inhabits (between power and authority and power and the sanctity of life) does not resemble a tight logic, and so a pluralist does not long for the 'Being of abandonment' beyond the paradox of sovereignty (in the manner of Agamben); instead she seeks to 'fold agonistic respect' into the exercise of sovereign power (pp. 137, 140, 147). Having made this point, the chapter switches to an analysis of the global 'sovereignty' of contemporary capitalist processes. Connolly embraces much of the detail of Michael Hardt and Antonio Negri's 'map' of the 'empire' of capital accumulation, but, again, he rejects the idea that this system is 'formed by a tight logic or design'. By way of contrast to their appeal to the singular agency of the global 'multitude' (and to the total transformation of capitalism): a pluralist advocates 'creative modes of intervention posed at several strategic sites in the service of reducing economic inequality, fostering...pluralism, and promoting ecological sanity' (p. 159).

The book is well written, stimulating, and challenging. Connolly demonstrates a consummate grasp of his subject, and his treatment of difficult philosophical arguments is outstanding. Each of the essays is well focused and tightly packed with insights. The detail of the arguments is often compelling. However, I am unconvinced by the central proposition of the book, that is, that the critical security of pluralism rests principally upon individual practices of 'agonistic respect'. This (ultimately 'idealist') defence of pluralism (with its 'call' to 'modesty', 'forbearance', and 'hospitality') is necessary but insufficient in a world threatened by gross forms of inequality, environmental collapse, and militant fundamentalisms. The attentive reader of Pluralism will pick up the faint whisper of an alternative defence of pluralism. Connolly accepts that it may be necessary to mobilize a more 'militant assemblage of pluralists' when 'pluralism is threatened by powerful unitarian forces that demand the end of pluralism' (p. 67). But what if this need is greater than Connolly supposes? What if the formation of a 'militant assemblage of pluralists' is actually a condition of the present and future flourishing of pluralism? Then the most pressing questions today would centre on how (strategically) to construct this 
assemblage. However, there is no systematic theoretical account of how to construct an overarching 'assemblage of pluralists' in Pluralism or elsewhere in Connolly's writings. This is on account of his basic 'optimism' that (more often than not) individual practices of 'agonistic respect' will suffice to bind the diversely faithful together. This is not optimism I share, but these criticisms do not lessen the significance of this book, which will be debated and read widely.

Mark Wenman University of Nottingham, UK.

\section{Why Deliberative Democracy?}

Amy Gutmann and Dennis Thompson

Princeton University Press, Princeton, NJ, 2004, ix +217 pp. ISBN: 0691120196.

Contemporary Political Theory (2007) 6, 125-127. doi:10.1057/palgrave.cpt.9300287

In this follow-up to their highly influential Democracy and Disagreement, Amy Gutmann and Dennis Thompson present a slightly less detailed and more focused account of their theory of deliberative democracy. All but the first chapter have been previously published and only slightly modified for the book. Taken together, the first four chapters provide a closer look at the theoretical motivations behind deliberative democracy, while at the same time highlighting the unique features of Gutmann and Thompson's account of deliberative democracy. In addition, Gutmann and Thompson also include two essays that illustrate how their account of deliberative democracy can be used to assess both current healthcare policy in the US and UK and South Africa's Truth and Reconciliation Commission.

Readers who have been keeping abreast of Gutmann and Thompson's work after the publication of Democracy and Disagreement will not find much of anything new in this text, with the exception of the first chapter, which provides a clear and quite persuasive introduction to deliberative democracy. Although the rest of the text consists of essays published over the last decade, a unifying theme is evident. Gutmann and Thompson aim to establish the moral foundations of deliberative democracy, thereby showing that deliberative democrats are committed to more than a certain set of decisions procedures. Gutmann and Thompson anchor their theory in the moral value of reciprocity and, ultimately, mutual respect. As Gutmann and Thompson understand it, reciprocity requires 'mutually respectful reasoning', thereby offering an account of deliberative virtue that is more demanding than the conceptions 